\title{
めつき業界における ナトリウムボロハイドライドの応用(下)
}

The Application of Sodium Borohydride (SBH)

to the Recovery of Precious Metals in Metal Finishing (Part II)

無電解めっき用還元剤, SBH とその誘導
体についての歴史, 現況をのべ, その関連と
してオーディオ界で話題のメタルテープの展 望, 更に公害防止, ガラス表面処理, 燃料電 池用電極材料などの SBH の用途を解説する。
伊 賀 久 矩*

Hisanori lga

\section{1． 無電解ニッケルめっき還元剂}

\section{1-1ＳBHによる無電解めっきの歴史}

SBH そょる無電解めっきについては, 1960年代に E.A. Sullivan ${ }^{1)}$ がニッケルその 他の金属適用し，また安定剂に特徽のある K. Lang のニボダー法”が発表され, 日本で は上村工業剓がバイエル社と共同で開発に尽 力されたことは広く知られている。

しかし, 日本に括汀る SBH 亿よる無電解 めっき(特にニッヶル)は, $\mathrm{pH}$ の制約, 或 いは特許の関係等で, 最近まで研究が停灃し ていたような感じをうける。この問題につい て, 以前, 業界の方々の色々な意見を調查す る機会があり，その当時期限切れ寸前の無電 解めっきの基本特許 ${ }^{3}$ があり, この特許住対 するあきらめの意識が非常に強かった。念の ためこの特許を調查したところ, 既に無効に なっていることが判明し, 関係者に連絡した ことがある。
最近の研究機関，業界共に SBH による無 電解めっきが改めて見直されるようになって きて扣り，実用面ではシアン化浴の無電解金 めっき汇かなり $\mathrm{SBH}$ が使用されている。こ れは多分 K. Okinaka4)のカリウム浴をナト リウム浴に変えた独自の浴組成が開発されて きていると考光られる。ほた，同じくシアン 化浴の無電解銀めっきも研究され, 実用に近 づいている。これは多分コルモーゲン・コー ポレーションの特許 ${ }^{5)}$ 等を応用しているので はないかと思われる。

ニッケル或いはコバルトの無電解めっきに 対して，SBH はあまり使われていない上う であるが，研究としては大阪府立大の林教授 始め数多〈の研究が行なわれている6)。

一方外国では, ニッケル或いはコバルト等 の無電解めっさの研究, 或いは特許が古くか ら数多くめり, $\mathrm{SBH}$ の他飞, 有機ホウ水素 化合物のジメチルアミンボラン (DMAB), 或いはジアミンボラン (DEAB) 等のアミン ボランを還元荗とする方法も研究され，数多
*日曹ベントロン(株) ・営業課長, 技術士

干100 東京都千代田区大手町2-2-1 新大手町ビル ङ03 (245) 6078
*Nisso-Ventron Co., Ltd.

Shin-Ohtemachi Building,

2-1,Ohtemachi 2-chome, Chiyoda-ku, Tokyo 100 
くの文献，特許が発表されている。

日本でも, 最近では同様な研究が散見され ており?，上村工業侏ではこのアミンボラン を還元剤とする高純度無電解ニッケル浴, "BEL ニッケル" の開発游力されている が，アミンボランの価格がかなり高価とのこ とである。他に 1 社アミンボランを還元剈と するニッケル無電解めっき調合液が輸入販売 されている。

\section{1-2 アミンボランと SBH について}

$\mathrm{R}_{3} \mathrm{~N}: \mathrm{BH}_{3}(\mathrm{R}$ は $\mathrm{H}$, 又アルキル基攵の他） で表わされる物質はアミンボランと呼ばれ， 既に述べた DMAB，DEAB はこのアミンボ ラン類である。無電解めっきの還元剤とし て，外国の特許にはこの他にプロピルアミン ボラン，トリメチルアミンボラン，ピリジン ボラン, ルチジンボラン等が記載されている が，特許の請求範囲を広くするための DMA Bからの連想と思われ，これらの還元剤を使 用した実施例は極めて少ない。 DEAB 䒠 施例は殆んどなく，大部分は DMAB の実施 例である。

\section{$\mathrm{SBH}$ を原料として DMAB 又は DEAB} を国内で安価供給し，日本のめっき業界飞 役立てようと色々と検討してみたが，残念な がら現在知られている合成法では，ますます 綮しさを加えている日本の法規の下ではDM $\mathrm{AB}, \mathrm{DEAB}$ の合成製造梳不可能に近いと思 われる。この理由を簡単に述べると， DMA $\mathrm{B}, \mathrm{DEAB}$ を製造する場合， $\mathrm{SBH}$ からジボ ラン $\left(\mathrm{B}_{2} \mathrm{H}_{6}\right)$ という毒物を製造する過程を経 由せねばならず,このジボランは猛毒のた め，極めて危険な合成法となり，とても日本 での製造許可は得られないと思われる。

しかし，このますではニッヶル等の無電解 用の還元剤は高価な輸入品にたよるか，或い は既述のように SBH を使用する方法を徹底 的江研究するか，をた安全で経済的な DMAB の合成法の研究も必要と思われる。

\section{1-3 ピリジンボランについて}

以上の考察の結果, $\mathrm{SBH}$ を原料としてD $\mathrm{MAB}$ 等に代替し得る, 安価で合成容易なア ミンボラン類を検討した。その結果, 既述の ピリジンボラン (PYAB) がジボランを経由 せず，SBH から比較的容易に合成できるこ とが判明した。

一方, 有機合成の分野では, PYAB は SB Hより弱い還元剤として研究されて和り，組 成的にはボランのルイス塩基付加物といわ れ，同類のもの之して $\mathrm{DMAB}, \mathrm{DEAB}$ が例 示されている。有機合成の特許で, 実施例が PYAB の及で特許請求範囲には DMAB，D $\mathrm{EAB}$ が含まれて扮り，ちょうど無電解めっ きの特許の逆の連想による特許請求範囲の取 り方となっているものがある ${ }^{8)}$

問題は性能として，果してPYAB が無電 解めっきの還元剤として有効であるかどらか である。大阪府立大学，林教授の下で PYA Bについて色々と基碟的炕検討していただ き，昨年11月の金属表面技術協会第58回学術 講演大会で中間発表され ${ }^{9}$ ，更に検討が進め られている。

PYAB を還元㓮とする無電解めっきの試 験を希望される場合，有償サンプルとして $\mathrm{P}$ YABを提供できるので問い合わせ願いたい。

\section{1-4 ホウ水素化合物によるニッケル等 の無電解めっきの現況}

ホウ水素化合物を還元剤とする無電解めっ きは, 初期汇は従来の次覀りン酸塩を還元剂 とする方法と競合すると思われていたが，現 在では周知のごとく, めっき膜の強度, 耐熱 性等に極めてすぐれて拈り，次西り酸塩還 元とは全く異ったものと理解されるようにな り, 将来が期待されている。

ホウ水素化合物を還元剂とする無電解めっ きの動向については，本誌（'77-11月号）に 上村工業秼の詳細な報交があるので参照され たい 
以上, ニッケル等の無電解めっきについて 還元剤を主体にをとめてみたが，SBH を還 元剂とする場合， $\mathrm{SBH}$ 粉末には固化防止剂 が含をれて特り，これが水に溶けないため， $\mathrm{SBH}$ 粉末を水に溶解して無電解めっき液に 添加する際，必ず汇過して不溶解を除く必要 がありこのことは案外知られていないので ご注意いただきたい。また，初歩的な疑問で あるが，なぜ金，銀と同様なシアン浴で SB Hを還元剤とするニッケル等の無電解めっき が研究されていないのか，技術的に無理な面 があるのかもしれないが，ご意見があればお゙ 知らせ願いたい。

\section{SBH のプラめっきへの応用}

めっき関係で，この他に $\mathrm{SBH}$ が使われて いる例は，プラスチックへのめっきの前処理 の工程, すなわち, 活性化処理工程で使用さ れている11。また，同じくプラスチックの銅 無電解めっきの還元剂として, 一時公害で問 題となったホルマリンのかわりに使用された ことがある12)。

\section{3. 磁気記録材と無電解めっき}

最近，オーディオ界で新登場したメタルテ 一プは色々と話題となったが，簡単に説明す れば,メタルテープの出現で磁気テープの記 録性が向上し，カセット方式でオープンリー ル並みの性能をこのメタルテープは出すこと ができるうえ，高密度記録ができるためビデ オテープに使用すればビデオコーダを小型化 することも可能といわれている。従来の磁気 テープはポリエステル等のテープの上に磁気 材料の酸化鉄，或いは酸化クロム等の微粉末 を塗っていたが，これに対しメタルテープは 磁気材料として鉄を主成分とし，コバルト等 を含む合金微粉末を使用している。
この合金微粉末の製造法は色々とあるが， $\mathrm{SBH}$ による水溶液還元が主流となってきて いる13)。具体的な方法は公表されていない が，一つの見方として合金成分の沶の沶のの 無電解めっさの条件を色々と変支て，微粉状 析出を行なわせる条件を応用しているるのと 思われる。この方法で特筆すべさことは， $\mathrm{S}$ $\mathrm{BH}$ 還元を行なら場合，塩類の水溶液を強力 磁場中に叔いてから $\mathrm{SBH}$ を添加して, 生成 する合金微粉末に磁性的に方向性を持たせて いる。しかもこの方法は，この分野で古くか ら公知の方法である。むしろ析出した微粒子 を酸化を防ぎながらテープの上に塗布する工 程がポイントだといわれている。

無電解めっきの立場から見れば，ポリエス テルのテープ素地に, 無電解めっさすること も当然考えられるが，長尺のテープに連続的 に，かつ，均一に無電解磁性めっきを行なう ことは技術的にどらであろうか。むしろ無電 解めっきは磁気記録テープ以外の磁気記録材 料（例えば，ディスクメモリー等）の磁性め っきとして次禹りン酸塩還元による無電解め っきが現在の主流であり報文す多い(14)。その 中にはホウ水素化合物還元の無電解めっきる あり,メタルテープとの関連でどのように展 開されるかが今後の問題と思われる。

\section{SBH による重金属公害防止}

外国では四エチル鉛工場の排水中の鉛除去 処理, 水銀法苛性ソーダ工場の排水中の水銀 除去等に SBH が使用されているが，日本に 特ける公害規制は遙に厳しく, 周知のごとく 四エチル鉛工場の操業は認められず, 水銀法 苛性ソーダ工場は転換促進中のため，いずれ も日本では $\mathrm{SBH}$ の用途として成立しない。

SBH の 還元力により 有害な重金属を還元 分離して除去できるが，回収物の評価は貴金 属を除く殆んぞの場合, 薬剤費などの処理費 
以下であるため，経済的沈無理がある。し かし，これは公害以前の回収業の考方方であ り，公害処理費といらことで考旮れば検討の 対象となる。すなわち, 高額の公害処理設備 を取付け，高額の償却費を負担する方法と設 備を簡略にして, SBH 還元で除害処理して, ランニングコストがやや高くなる方法との比 較ということになり, めっき業も含めて検討 の対象となってきている。

極端な例として，㘯る重金属の公害処理に $て$, 廃液集荷, 集中除害処理のシステムが完 成しているが，廃液集荷費が非常に高いコス トになっている場合がある。この場合, 廃液 中の重金属をSBH で還元し，沈殿物のみの 集荷を行な学ば，相当汇集荷コストが低減で きるので検討中のものがある。

\section{〔ビルディング等のガラスの表面処理による 断熱について〕}

ビルディング等に使用されるガラスの表面 に, 透明に近いニッケル，コバルト等の薄膜 を SBH を還元戍とする無電解めっさ法によ り生成させ, 輻射熱の反射に上り断熱し, 建 物の暖冷房を省エネルギーする方法が米国等 で行なわれている15)。日本では，まだこの方 法は普及していないが，一部で化学的方法に より，酸化チタン等の薄膜をガラスの表面に 生成させ，同様な効果をもたらす方法が行な われている。

\section{5. 燃料電池用電極材料}

$\mathrm{SBH}$ は分子量当りの水素含有量が高い( 約 10\%) ため, 非常用の燃料電池の水素源とし てこの分野に知られているが，経済的には疑 問である。しかし，外国で試作されている酸 水素燃料電池の電極材料の白金を節減する助 剤 $\mathrm{Ni}_{2} \mathrm{~B}$ （触媒ともいわれている）の製造に
$\mathrm{SBH}$ の 使用が期待されている16)。これにつ いては, ニッケルの無電解めっきで $\mathrm{pH}$ を中 性に近づけると $\mathrm{Ni}-\mathrm{B}$ の混合析出中の $\mathrm{B}$ の含 量が多くなるという，めっき関係では周知の 技術が応用できる。

\section{6.むすび}

以上，めっさ業界およびそれ関連した金 属関係での SBH の用途について解説した。 これらの $\mathrm{SBH}$ の用途に対して, 日本での $\mathrm{S}$ $\mathrm{BH}$ の使用量はまだ極めて少なく, 今後の拡 大が期待されている。

\section{文献}

1) U.S.P. 2, 492, 990 Ventron Corp.

2) Metalloberfläche, 19, 257 (1965)

3 ）特公昭37一6111, バイエル A.G.

4) J. Electrochem Soc., 121, 56 (1974)

$5 ）$ 特公昭 $52-28729$, コルモーゲン・コーポ レーション (USA)

6) 松岡活办; 電気化学，41，211 (1973) 沢井活か；電気化学， 43，721（1975） 渡辺注加；金属表面技術，25，36(1974）

7 ) 沢井活加; 電気化学, 44, 402 (1976)

8 ) 特許出願中一 1977 , 城西大学

9) 松阔浮功, 第58回学術講演大会要旨集,

50 (1978，金属表面技術協会)

10）大高；実務表面技術，11月号，528 (1977)

11）特公昭 $52-16696, ソ ニ ー$ 姝

12）特開昭52-59028, 奥野製薬工業姝

13）特開昭50一41756, 富士写真フイルム秼

14）鷹野；金属表面技術，28，541（1977）

15) U.S.P. $3,672,939$ PPG Industries Inc.

16) U.S.P. $3,183,124$ Allis-Chalmers

Manufacturing Co. 